\title{
Efficacy of Spirulina (Tahlab) in Patients of Type 2 Diabetes Mellitus (Ziabetus Shakri) - A Randomized Controlled Trial
}

\author{
Anzar Alam ${ }^{1 *}$, Siddiqui MA², Aleemuddin Quamri², Sana Fatima ${ }^{3}$, Mariyam Roqaiya ${ }^{4}$ and Zaheer Ahmad \\ ${ }^{1}$ Department of Moalajat, Luqman Unani Medical College Hospital and Research Centre, Bijapur, Karnataka, India \\ ${ }^{2}$ Department of Moalajat, National Institute of Unani Medicine, Kottigepalya, Bengaluru, Karnataka, India \\ ${ }^{3}$ Department of Pharmacy, National Institute of Unani Medicine, Kottigepalya, Bengaluru, Karnataka, India \\ ${ }^{4}$ Department of IImul Qabala wa Amraze Niswan, Luqman Unani Medical College Hospital and Research Centre, Bijapur, Karnataka, India \\ ${ }^{5}$ Research Officer (Unani) S-4, RRIUM, Chennai, India
}

\begin{abstract}
Aims: Diabetes mellitus (DM) (Ziabetus Shakri) is a common metabolic disease affecting 150,000,000 people worldwide. Despite the recent advancements in management of Diabetes its relative co-morbidities and mortality is ever increasing globally. Unani scholars had claimed the effectiveness of several anti-diabetic drugs in the classical texts in the management of DM, but it lacks scientific documentation. Hence, a clinical trial was contemplated to evaluate the efficacy of test drug Tahlab (Spirulina) in patients of type 2 DM.

Methods: The study was a single blind randomized standard control conducted on 40 patients of type $2 \mathrm{DM} .30$ subjects were allocated to test and 10 to control group. Test group received 7 grams of Tahlab powder twice a day, and control group received Metformin $(500 \mathrm{mg}) 1$ tablet twice a day for a period of 45 days. Subjective and objective parameters were assessed at $0,15^{\text {th }}, 30^{\text {th }}, 45^{\text {th }}$ day.

Results: The Mean score for FBS in test group has declined from 245.53 to 204.87 and PPBS from 345.73 to 303.67 respectively. The Mean score for FBS in control group has declined from 227.60 to 191.80 and PPBS from 329.60 to 282.80 respectively. Intergroup comparison revealed test drug to be similar to that of control drug in reducing FBS and PPBS. HbA1c and urine sugar remained unaltered in both groups. The results were assessed statistically using two tailed student $t$ test, paired proportion test and Fischer exact test.
\end{abstract}

Conclusions: The study revealed that the test drug is safe and equally effective when compared to control drug

Keywords: Type 2 Diabetes mellitus; Spirulina; Tahlab; Ziabetus

\section{Highlights}

- Tahlab (Spirulina) has been claimed by the ancient Unani physicians in the classical texts to be effective in the treatment of Diabetes like condition.

- Globally strenuous efforts are underway to explore herbal therapies to treat Diabetes mellitus which has become a menace for the Asian population as its prevalence is increasing at an alarming rate.

- Tahlab has been found to be equally effective when compared to control drug sans adverse effects.

\section{Introduction}

Diabetes mellitus (DM) is a metabolic disorder with multiple etiologies, characterized by chronic hyperglycemia with disturbances of carbohydrate, fat and protein metabolism resulting from defects in insulin secretion, insulin action or both [1]. In Unani classical text diabetes is described by renowned Unani scholars like Zakaria Razi, Ali Ibn Abbas Majoosi, Ibn Sina, Ismail Jurjani, Ibn Zuhar, Ibn Hubal Baghdadi, with various names such as; Ziabetus, Moattasha, Atsha, Intesae Anmas, Zalaqul kulliya, Dolab, Dawwarah, Barkar, Barkarya, Qaramees etc. [2-7]. Long term effect of diabetes leads to various complications viz., diabetic nephropathy, neuropathy, retinopathy, diabetic foot, charcot joints and sexual dysfunction [8,9]. People with diabetes are at increased risk of cardiovascular, peripheral vascular and cerebrovascular diseases [10]. Worldwide prevalence of diabetes was estimated to $8.3 \%$ with age between 40 to 59 years and $46 \%$ of cases undiagnosed in 2013, with India alone accounting for 65.1 million and in China 98.4 million patients. It may shoot up to $55 \%$ by the year 2035. Half of the people with diabetes do not know they have it, $80 \%$ people with diabetes live in low and middle income countries, half of the people who die from diabetes are under the age of 60 . Every six seconds a person dies from diabetes. The cost of diabetes care is enormous and escalating worldwide. It is estimated $11 \%$ ( 548 billion USD) is spent on diabetes treatment [11].

According to Unani scholars, diabetes is considered as disease of kidney and it is due to four causative factors (i) zofe kuliya (weakness of kidney) (ii) Ittesae kuliya wa majrae bole (dilatation of kidney and tubule) (iii) sue mizaj haar kuliya (derangement of temperament of kidney due to heat) and (iv) sue mizaj barid kuliya (derangement of temperament of kidney due to cold) [2-7].

Unfortunately, ntil date there is no appropriate therapeutic intervention to treat the diabetes. Currently, biguanides, sulphonylureas, insulin and including DPP-4 Inhibitors are used to manage the diabetes

*Corresponding author: Dr. Anzar Alam, Assistant Professor, Department of Moalajat, Luqman Unani Medical College, 12 Naubag, Bijapur, Karnataka, India, Tel: +91-9902146030; E-mail: dranzarnium@gmail.com

Received August 22, 2016; Accepted October 18, 2016; Published October 25 2016

Citation: Alam A, Siddiqui MA, Quamri A, Fatima S, Roqaiya M, et al. (2016) Efficacy of Spirulina (Tahlab) in Patients of Type 2 Diabetes Mellitus (Ziabetus Shakri) - A Randomized Controlled Trial. J Diabetes Metab 7: 710. doi: 10.4172/2155 6156.1000710

Copyright: (c) 2016 Alam A, et al. This is an open-access article distributed unde the terms of the Creative Commons Attribution License, which permits unrestricted use, distribution, and reproduction in any medium, provided the original author and source are credited. 
[12]. Long terms usage of these drugs leads to various complications and adverse effects; renal problem, hypoglycemia, gastro intestinal tract (GIT) disturbance and cardiac problems [13]. The above fact necessitates the exploration of time tested, effective and safe Unani treatment for the management of diabetes.

Currently, Spirulina (a single cell filamentous algae, richest source of protein, nature best food) is documented as; antioxidant \& immunomodulator [14], hepatoprotective [15], nutraceutical [16], nephroprotective [17] neuroprotective [18], cardioprotective [19], anticarcinogenic [20], anti dyslipdeamic and anti hyperglycaemic activity [21]. Another study reported that insulin like protein is found in Spirulina [22].

In Unani literature Spirulina is described by the name of tahlab which means green vegetation substance sticking to the walls of pond water and was used in the management of diabetes from ancient times and its action is ascribed to its baroodat wa yaboosat (cold and dry) temperamental property and astringent activity. Most of the antidiabetics Unani drugs are astringenic in action including tahlab $[23,24]$.

A number of independent preclinical and clinical studies support the antihyperglycaemic and antidyslipidaemic activity for spirulina [21,25-32]. These observations led us to contemplate the study to evaluate the safety and efficacy of spirulina (tahlab) in the management of Type 2 Diabetes in human subjects.

\section{Materials and Methods}

A randomized single blind standard controlled trial was conducted during March 2014 to July 2014 at the O.P.D of N.I.U.M, Bengaluru. The study protocol was approved by the Institutional Ethical Committee of National Institute of Unani Medicine, Karnataka (IEC No: NIUM/ IEC/2012-13/001/Moal/01). The test drug Spirulina was procured from Avantha Holdings Limited Spirulina Biotech Division, K.I.A.D.B. Industrial Area, Nanjangud Karnataka-571302, in the form of powder. Each patient in test group was given spirulina in a dose of $7 \mathrm{~g}$ twice a day in powder form and the control drug Glycomet (Metformin) (Manufactured by USV Company) in a dose of $500 \mathrm{mg}$, one tablet was given orally twice a day before meal for 45 days.

Selection criteria include diagnosed cases of type $2 \mathrm{DM}$ with Fasting Blood Sugar (FBS) $>126 \mathrm{mg} / \mathrm{dl}$, Post Prandial Blood Sugar (PPBS) $>200 \mathrm{mg} / \mathrm{dl}, \mathrm{HbAlc}>6.5 \%$ and aged between $30-60$ years of either gender, patients willing to participate in the study and ready to follow the instructions. Exclusion criteria include pregnant and lactating women malnutrition related diabetes mellitus, diabetic ketoacidosis, retinopathy, neuropathy, nephropathy, coronary artery diseases, peripheral vascular disease, cerebrovascular disease, liver disease and impaired organ functions (Figure 1).

A total no of 40 subjects of diabetes fulfilling the inclusion criteria were randomly assigned to the test and standard controlled group by simple randomization method after taking voluntary informed consent. Thirty subjects were allocated to test group and 10 subjects to the standard control group. Subjective parameters (polyuria, polydipsia, polyphagia and tiredness) were assessed at baseline and follow up visits $\left(15^{\text {th }}, 30^{\text {th }}\right.$ and $45^{\text {th }}$ days $)$ and assessment of objective parameters (fasting blood sugar, post prandial blood sugar, HbAlc and urine sugar) were carried out on pre and post (i.e. $0^{\text {th }}$ and $45^{\text {th }}$ days) study period.

Descriptive and inferential statistical analysis was carried out in the present study. Results on continuous measurements were presented as Mean \pm SD (Min-Max) and results on categorical measurements are presented in Number (\%). Significance is assessed at $5 \%$ level of significance. Student $t$ test (two tailed, independent) was used to find the significance of study parameters on continuous scale between two groups (Inter group analysis) on metric parameters and Student t test (two tailed, dependent) has been used to find the significance of study parameters on continuous scale within each group. Chi-square/ Fisher Exact test has been used to find the significance of study parameters on categorical scale between two or more groups. Paired Proportion test has been used to find the significance of proportion in paired data using standard statistical software. The Statistical software SAS 9.2, SPSS 15.0,

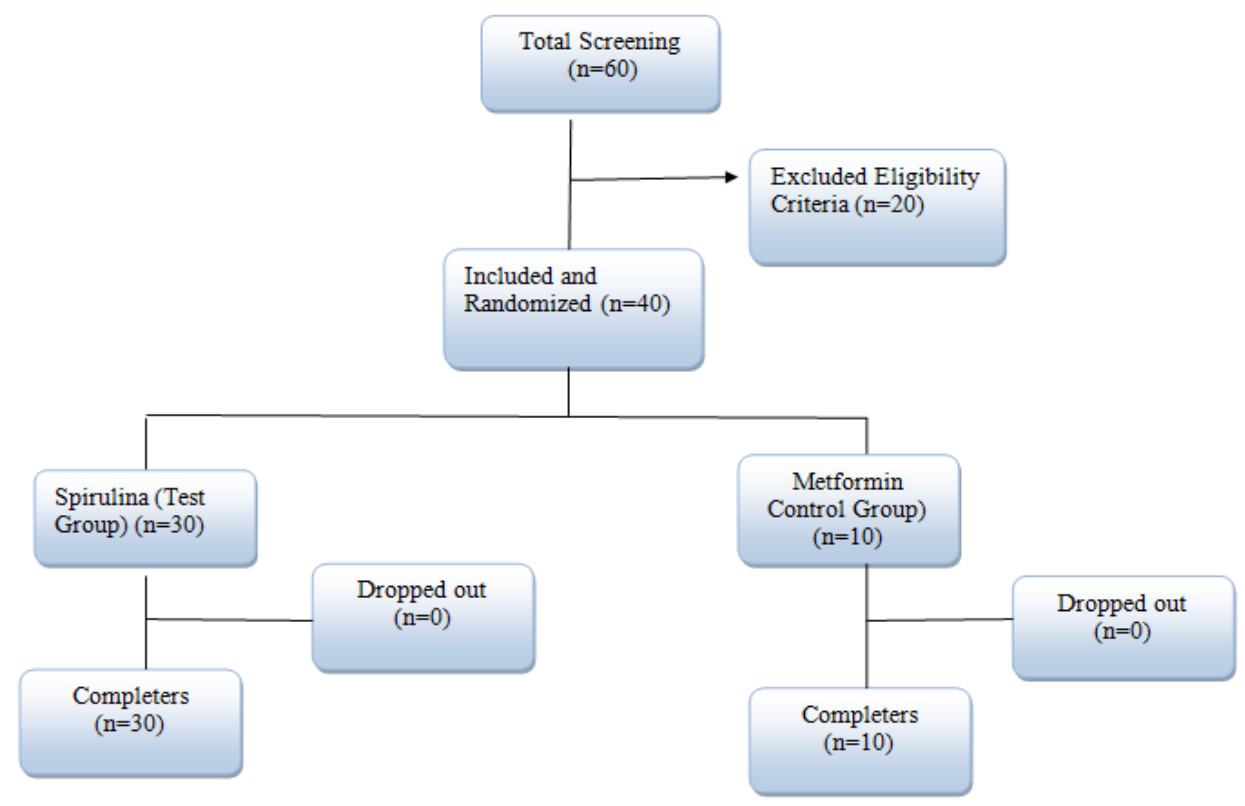

Figure 1: Selection criteria. 
Stata 10.1, Med Calc 9.0.1, Systat 12.0 and R environment ver.2.11.1 were used for the analysis of the data.

\section{Results and Discussion}

As depicted in Table 1 that maximum number of patients 28 (70\%) were recruited in age group of 41-60 years and only $12(30 \%)$ were $<40$ years. According to IDF Diabetes Atlas 6th Edition, 382 million people with diabetes are aged between 40 and 59 years [11]. This study coincides with the IDF finding as more numbers of subjects were between 41-50 years followed by 51-60 years. Highest incidence 30 (75\%) was observed in male patients while 10 (25\%) are female patients. This study finding support the claim made by Khalid et al. that prevalence of diabetes is more among males than in females [33]. Out of 40 patients, 32(80\%) were found to be normal without any concomitant diseases, whereas, $7(17.5 \%)$ were hypertensive and $1(2.5 \%)$ had complicated diabetes mellitus (Table 1). Samuels et al. made almost similar observations [34]. The duration of illness was between 24-60 months in 9 (22.5\%) patients, $12-24$ months in $14(35 \%)$ patients, $7-12$ months in $4(10 \%)$, 4-6 months in 3 (7.5\%), 1-3 months in 5 (12.5\%), and >60 months in $5(12.5 \%)$ (Table 1). Verma et al. reported that tendency of diabetes increases with increasing duration of illness, which is not consistent with the study due to low sample size [35]. Dietary habit was mixed in $39(97.5 \%)$ patients and only $1(2.5 \%)$ patient was pure vegetarian (Table 1). Tonstad et al. reported that DM more is common in nonvegetarians than vegetarians and vegetarians had low risk of type-2 diabetes than non-vegetarians [36]. Among 40 patients, 24 (60\%) had positive family history of DM (Table 1). Shah et al. reported that family history of diabetes is the predisposing factor for type-2 DM [10].

\section{Effect on subjective parameters}

Test and control groups were assessed for polyuria on the arbitrary rating scale of nil, mild, moderate and severe polyuria. It was found that test group showed $56.6 \%$ reduction in polyuria compared to $80 \%$ reduction in control group. In both the groups, the reduction in polyuria was significant statistically $\left(\mathrm{P}<0.001^{* *}\right)$. Reduction of polyuria in test group may be due to Qabiz (astringent) property of Spirulina (Tahlab) [37]. In polydipsia, 60\% improvement in test group compared to $0 \%$ in Nil and $10 \%$ in mild category, which is statistically significant $\left(\mathrm{P}<0.001^{* *}\right)$ at 45 th day compared to control group $(\mathrm{P}=0.069+)$. The effect may be due to Musakkin Atash, Qabiz and Mubarrid property of the drug described by Zakaria Rhazi, Ibn Baitar, Hkm. Kabiruddin [37-39]. Polyphagia has significantly improved $\left(\mathrm{P}<0.001^{* *}\right)$ to $40 \%$ in test group compared to $10 \%$ in controls which may be due to highly nutrious and energetic effect of spirulina reported by Ravi et al. [14]. Tiredness is improved in $40 \%$ cases in test group compared to $20 \%$ in control group. Park et al. [39] reported that Spirulina contains various vitamins and minerals, which act as immunomodulators and antioxidant properties, which prevent the formation of lactic acid and reduced the tiredness [40].

\section{Objective parameters}

The Mean \pm SEM score for FBS in Test Group on 0th day and 45th day was $245.53 \pm 78.95$ and $204.87 \pm 78.15$ respectively, with a difference of 40.667. The Mean \pm SEM score $227.60 \pm 67.85$ and 191.80 \pm 78.91 on 0 th day and 45 th day respectively, with a difference of 35.800 in Control Group which is statistically significant (Table 2). Parikh et al. affirmed that spirulina is rich source of fibre contents which may leads to reduced glucose absorption and possible action of peptides and polypeptides generated by digestion of spirulina protein are responsible for it [21]. Kumari et al. [26], Anitha et al. [30], Lee et al. [31], Kaur et

al. [32], and Layam et al. [41], reported that Spirulina exhibit antihyperglycemic activity.

The Mean \pm SEM score for PPBS in Test Group was $345.73 \pm$ 98.33and $303.67 \pm 96$ on 0th day and 45th day respectively, with a difference 42.067 . The mean \pm SEM score in control group has declined from $329.60 \pm 72.92$ to $282.80 \pm 99.90$ on 0th day and 45th day respectively, with a difference of 46.800 , which is statistically moderately significant (Table 2). Parikh et al. and Anwer et al., reported that Spirulina provides plentiful source of proteins and it is well recognized that ingestion of protein and amino acids which stimulates the secretion of insulin. This effect may be responsible for reduction in PPBS [21,22].

The Mean \pm SEM score for HbAlc in Test Group as observed on 0th day and 45th day was $9.73 \pm 1.92$ to $9.95 \pm 2.11$ respectively, with a difference of 0.220 . The Mean \pm SEM score observed in control group was $9.61 \pm 1.49$ to $9.15 \pm 2.03$ on 0th day and 45th day respectively, with a difference of 0.460 in Control Group (Tables 3 and 4). When Mean

\begin{tabular}{|c|c|c|c|}
\hline & Test Group & Control Group & Total \\
\hline \multicolumn{4}{|l|}{ Age in years } \\
\hline$<30$ & $1(3.3 \%)$ & $0(0 \%)$ & $1(2.5 \%)$ \\
\hline $31-40$ & $7(23.3 \%)$ & $4(40 \%)$ & $11(27.5 \%)$ \\
\hline $41-50$ & $16(53.3 \%)$ & $4(40 \%)$ & $20(50 \%)$ \\
\hline $51-60$ & $6(20 \%)$ & $2(20 \%)$ & $8(20 \%)$ \\
\hline Total & $30(100 \%)$ & $10(100 \%)$ & $40(100 \%)$ \\
\hline Mean $\pm S D$ & $45.07 \pm 7.67$ & $44.00 \pm 9.39$ & $44.80 \pm 8.02$ \\
\hline \multicolumn{4}{|l|}{ Family history } \\
\hline $\mathrm{DM}$ & $18(60 \%)$ & $6(60 \%)$ & $24(60 \%)$ \\
\hline NS & $12(40 \%)$ & $4(40 \%)$ & $16(40 \%)$ \\
\hline Total & $30(100 \%)$ & $10(100 \%)$ & $40(100 \%)$ \\
\hline \multicolumn{4}{|l|}{ Past history } \\
\hline NS & $23(76.7 \%)$ & $9(90 \%)$ & $32(80 \%)$ \\
\hline HTN & $7(23.3 \%)$ & $0(0 \%)$ & $7(17.5 \%)$ \\
\hline DM & $0(0 \%)$ & $1(10 \%)$ & $1(2.5 \%)$ \\
\hline \multicolumn{4}{|l|}{ Duration of IIIness } \\
\hline 1-3 months & $4(13.3 \%)$ & $1(10 \%)$ & $5(12.5 \%)$ \\
\hline 4-6 months & $2(6.7 \%)$ & $1(10 \%)$ & $3(7.5 \%)$ \\
\hline $7-12$ months & $3(10 \%)$ & $1(10 \%)$ & $4(10 \%)$ \\
\hline $12-24$ months & $9(30 \%)$ & $5(50 \%)$ & $14(35 \%)$ \\
\hline 24-60 months & $8(26.7 \%)$ & $1(10 \%)$ & $9(22.5 \%)$ \\
\hline$>60$ months & $4(13.3 \%)$ & $1(10 \%)$ & $5(12.5 \%)$ \\
\hline Total & $30(100 \%)$ & $10(100 \%)$ & $40(100 \%)$ \\
\hline \multicolumn{4}{|l|}{ Dietary habits } \\
\hline Mixed & $29(96.7 \%)$ & $10(100 \%)$ & $39(97.5 \%)$ \\
\hline Veg. & $1(3.3 \%)$ & $0(0 \%)$ & $1(2.5 \%)$ \\
\hline Total & $30(100 \%)$ & $10(100 \%)$ & $40(100 \%)$ \\
\hline
\end{tabular}

Table 1: Demographic profile of the patients in the study groups.

\begin{tabular}{|c|c|c|c|c|}
\hline FBS & Test Group & Control Group & Total & P value \\
\hline Oth day & $245.53 \pm 78.95$ & $227.60 \pm 67.85$ & $241.05 \pm 75.89$ & 0.525 \\
\hline 45th day & $204.87 \pm 78.15$ & $191.80 \pm 78.91$ & $201.60 \pm 77.53$ & 0.65 \\
\hline Difference & 40.667 & 35.8 & 39.45 & - \\
\hline P value & $0.003^{* *}$ & 0.212 & $0.001^{* *}$ & - \\
\hline PPBS & & & & \\
\hline Oth day & $345.73 \pm 98.33$ & $329.60 \pm 72.92$ & $341.70 \pm 92.01$ & 0.637 \\
\hline 45th day & $303.67 \pm 96.16$ & $282.80 \pm 99.90$ & $298.45 \pm 96.24$ & 0.56 \\
\hline Difference & 42.067 & 46.8 & 43.25 & - \\
\hline \multicolumn{5}{|c|}{ Table 2: FBS $(\mathrm{mg} / \mathrm{dl})$ in two groups of patients studied. } \\
\hline
\end{tabular}


Citation: Alam A, Siddiqui MA, Quamri A, Fatima S, Roqaiya M, et al. (2016) Efficacy of Spirulina (Tahlab) in Patients of Type 2 Diabetes Mellitus (Ziabetus Shakri) - A Randomized Controlled Trial. J Diabetes Metab 7: 710. doi: 10.4172/2155-6156.1000710

Page 4 of 5

\begin{tabular}{|c|c|c|c|c|}
\hline HbA1c & Test Group & Control Group & Total & P value \\
\hline Oth day & $9.73 \pm 1.92$ & $9.61 \pm 1.49$ & $9.70 \pm 1.80$ & 0.862 \\
\hline 45th day & $9.95 \pm 2.11$ & $9.15 \pm 2.03$ & $9.75 \pm 2.09$ & 0.303 \\
\hline Difference & 0.22 & 0.46 & 0.05 & - \\
\hline P value & 0.525 & 0.459 & 0.867 & - \\
\hline
\end{tabular}

Table 3: HbA1c in two groups of patients studied.

\begin{tabular}{|c|c|c|c|}
\hline Urine Sugar & $\mathbf{0 ~ d}$ & $\mathbf{4 5} \mathbf{d}$ & $\%$ change \\
\hline Test Group $(\mathrm{n}=30)$ & & & \\
\hline Nil & $7(23.3 \%)$ & $8(26.7 \%)$ & $3.40 \%$ \\
\hline Trace & $0(0 \%)$ & $3(10 \%)$ & $10.00 \%$ \\
\hline 0.5 & $2(6.7 \%)$ & $2(6.7 \%)$ & $0.00 \%$ \\
\hline 1 & $5(16.7 \%)$ & $4(13.3 \%)$ & $-3.40 \%$ \\
\hline 1.5 & $2(6.7 \%)$ & $1(3.3 \%)$ & $-3.40 \%$ \\
\hline 2 & $13(43.3 \%)$ & $12(40 \%)$ & $-3.30 \%$ \\
\hline 2.1 & $1(3.3 \%)$ & $0(0 \%)$ & $-3.30 \%$ \\
\hline Control Group (n=10) & & & \\
\hline Nil & $1(10 \%)$ & $4(40 \%)$ & $30.00 \%$ \\
\hline Trace & $0(0 \%)$ & $1(10 \%)$ & $10.00 \%$ \\
\hline 0.5 & $2(20 \%)$ & $0(0 \%)$ & $-20.00 \%$ \\
\hline 1 & $2(20 \%)$ & $1(10 \%)$ & $-10.00 \%$ \\
\hline 1.5 & $2(20 \%)$ & $1(10 \%)$ & $-10.00 \%$ \\
\hline 2 & $3(30 \%)$ & $3(30 \%)$ & $0.00 \%$ \\
\hline 2.1 & $0(0 \%)$ & $0(0 \%)$ & $0.00 \%$ \\
\hline P value & 0.518 & 0.926 & - \\
\hline
\end{tabular}

Table 4: Urine Sugar in two groups of patients studied.

\pm SEM score of HbAlc in both groups were compared statistically by using Student $t$ test (two tailed, independent) it was found to be insignificant.

No change in the sugar in urine was observed in both the groups when compared statistically. The safety and tolerability of both test and control drugs were assessed at pre and post treatment i.e. $\mathrm{Hb} \%$, TLC and DLC, Blood Urea, Serum Creatinine, SGOT, SGPT, Urine Routine, Urine Microscopic, and ECG. The study revealed that all the safety parameters were within the normal range, and did not exhibit any significant difference demonstrating the tolerability of the test and control drugs.

The limitations of the study are small sample size, shorter duration of therapy, non-performance of serum insulin test etc. Hence, this trial open up new vistas in the exploration of herbal origin drugs in the management of DM and may serve as basal information to conduct more stringent studies in future.

\section{Conclusion}

The study has further enhanced and revealed the hypoglycemic nature of the test drug Spirulina. The reduction of subjective and objective parameters like polyuria, polydipsia, polyphagia, tiredness and FBS and PPBS demonstrate the utility of the intervention. Safety parameters remained within the normal range in both the groups throughout the course of trial suggesting that there is no Hepato/ nephro toxicity. The study revealed the potential hypoglycemic activity of the test drug. However, a long-term study with a larger sample size is imperative to further validate its pharmacological actions.

\section{Acknowledgement}

The authors are thankful to R. Sarada, Senior Principal Scientist C.F.T.R.I, Mysore for providing Spirulina powder for this trial.

\section{Funding}

Financial support for this study was provided by N.I.U.M, Bengaluru under Ministry of AYUSH, Govt. of India.

\section{Conflict of Interest}

Authors declare that there is no any conflict of interest involved in this study.

\section{References}

1. Abebe SM, Balcha SA (2012) The Effect of Supervised Progressive Resistance Training (PRT) on Glycemic Control and Cardio Vascular Disease (CVD) Risk Markers in Type 2 Diabetes Patients, North West Ethiopian. J Diabetes Metab 3: $1-5$.

2. Rhazi Z, Al-Hawi (2002) Fit Tib Central Council for Research in Unani Medicine New Delhi. Ministry of Health \& Family Welfare. Govt of India 2: 181-187.

3. Majusi AIA, Kamil Al-San't (2010) Central Council for Research in Unan Medicine New Delhi. Ministry of Health \& Family Welfare. Govt. of India 21: 192-193.

4. Sina I, Al-Qanoon (2010) Fit Tib. New Delhi 20: 1031-1033.

5. Jurjani I, Shahi ZK (2010) Urdu Translation by Hkm. Hadi Husain. Published By Idara Kitab Us Shifa New Delhi 10: 540-541.

6. Zuhr I, Kitab Al-Taiseer (1986) Central Council for Research in Unani Medicine New Delhi. Ministry of Health \& Family Welfare, Govt. of India 12: 160-163.

7. Baghdadi IH, Al Mukhtaratfit-Tibb K (2004) Central Council for Research in Unani Medicine New Delhi. Ministry of Health \& Family Welfare, Govt. of India 24: 326-328.

8. Prasad YD, Sonia S, Balvinder S, Charan CR (2013) Ig Glycation and Diabetes: A Review. Scholars Acad J Biosci 1: 59-66.

9. Cefalu WT (2016) Micro vascular Complications and Foot Care. American Diabetes Association Standards of Medical Care in Diabetes. Diabetes Care 39: S72-S80.

10. Shah SN (2012) 9th Edition; Jaypee Brothers. New Delhi 12: 321-323.

11. Anonymous (2013) International Diabetes Federation. Diabetes Atlas 2: 13-20.

12. Hardman JG, Limbird Lee E (2001) Goodman and Gilman's Pharmacological basis of Therapeutics diabetes 20: 1701-1706.

13. Panicker GK, Karnad DR, Salvi V, Kothari S (2012) Cardiovascular risk of oral antidiabetic drugs: current evidence and regulatory requirements for new drugs. J Assoc Physicians India 60: 56-61.

14. Ravi M, De SL, Azharuddin S, Paul SFD (2010) The Beneficial Effects of Spirulina Focusing On Its Immunomodulatory and Antioxidant Properties. Nutri Diet Suppl 2: 73-83.

15. Mazkopakis EE, Papadomalaki MG, Fousteris AA, Kotsiris DA, Lampadakis IL, et al. (2014) The hepatoprotective and hypolipidemic effects of Spirulina (Arthrospira platensis) supplementation in a Cretan population with nonalcoholic fatty liver disease: a prospective pilot study. Ann Gastroenterol 27: 387-394.

16. Laquna HBD, Marante FJT, Freire KRL, Mioso R (2015) Extraction of nutraceuticals from Spirulina (blue-green alga): A bioorganic chemistry practice using thin-layer chromatography. Biochem Mol Biol Educ 43: 366-369.

17. Khan M, Shobha JC, Mohan IK, Naidu MUR, Prayag A, et al. (2006) Spirulina attenuates cyclosporine-induced nephrotoxicity in rats. J Appl Toxicol 26: 444-451.

18. Pabon MM, Jernberg JN, Morganti J, Contreras J, Hudson CE, et al. (2012) A spirulina-enhanced diet provides neuroprotection in an $\beta$-synuclein model of Parkinson's disease. PLoS One 7: e45256.

19. Ibrahim AE, Abdel-Daim MM (2015) Modulating Effects of Spirulina platensis against Tilmicosin-Induced Cardiotoxicity in Mice. Cell J 17: 137-144.

20. Mathew B, Sankaranarayanan R, Nair PP, Varghese C, Somanathan T, et al (1995) Evaluation of chemoprevention of oral cancer with Spirulina fusiformis. Nutr Cancer 24: 197-202.

21. Parikh $P$, Mani U, lyer $U$ (2001) Role of Spirulina in the Control of Glycemia and Lipidemia in Type 2 Diabetes Mellitus. J Med Food 4: 193-199.

22. Anwer R, Alam A, Khursheed S, Kashif SM, Kabir H (2013) Spirulina; Possible Pharmacological Evaluation of Insulin Like Protein. J Appl Phycol 25: 883-889. 
Citation: Alam A, Siddiqui MA, Quamri A, Fatima S, Roqaiya M, et al. (2016) Efficacy of Spirulina (Tahlab) in Patients of Type 2 Diabetes Mellitus (Ziabetus Shakri) - A Randomized Controlled Trial. J Diabetes Metab 7: 710. doi: 10.4172/2155-6156.1000710

Page 5 of 5

23. Khan MA, Akseer-E-Azam (2011) Urdu Translation by Hkm. Kabeeruddin. Idara Kitab Us Shifa New Delhi 22: 705-709.

24. Anzar MA, Nafis H, Tanwir MA (2013) Drugs Indicated For The Management of Ziabetus Shakri (Diabetes Mellitus) In Unani Medicine -An Overview. Int J Pharmame India 1: 460-474.

25. Pandey JP, Tiwari A, Mishra G, Mishra RM (2011) Role Of Spirulina Maxima In The Control Of Blood Glucose Levels And Body Weight In Streptozotocin Induced Diabetic Male Wistar Rats. J Alga Biomass Utiliz 2: 35-37.

26. Kumari P, Khanam S, Varma MC, Kumar P, Chouhan R, et al. (2013) Study The Spirulina As A Potential Antidiabatic. Journal of Chemical. Biol Phy Sci 3: 1963-1971.

27. Pankaj PP, Varma MC (2013) Potential Role of Spirulina Platensis In Maintaining Blood Parameters In Alloxan Induced Diabetic Mice. Int J Pharm Pharmaceut Sci 5: 450-456.

28. El-Baz FK, Aly HF, El-Sayed AB, Amal AM (2013) Role of Spirulina Platensisin Thecontrol of Glycemia in DM2 Rats. Int J Sci Eng Res 4:1731-1740.

29. Moura LP, Puga GM, Beck WR, Teixeira IP, Ghezzi AC, et al. (2011) Exercise and spirulina control non-alcoholic hepatic steatosis and lipid profile in diabetic Wistar rats. Lipids Health Dis 10: 77

30. Anitha L, Chandralekha K (2010) Effect of Supplementation of Spirulina on Blood Glucose, Glycosylated Hemoglobin and Lipid Profile of Male Non- Insulin Dependent Diabetics. Asian J Exp Biol Sci 1: 36-46.

31. Lee EH, Park JE, Choi YJ, Huh KB, Kim WY (2008) A Randomized Study To Establish The Effects of Spirulina In Type 2 Diabetes Mellitus Patients. Nutri Res Pract 2: 295-300
32. Kaur K, Sachdeva R, Grover K (2008) Effect of supplementation of spirulina on blood glucose and lipid profile of the non-insulin dependent diabetic male subjects. J Dairying Foods \& HS 27: 202-208.

33. Khalid A, Alqurashi, Khalid S, Aljabri, Bokhari SA (2011) Prevalence of diabetes mellitus in a saudi community. Ann Saudi Med 31: 19-23.

34. Samuels R, Mani UV, lyer UM, Nayak US (2002) Hypocholesterolemic effect of spirulina in patients with hyperlipidemic nephrotic syndrome. J Med Food 5: 91-96.

35. Verma M, Paneri S, Badi P, Raman PG (2006) Effect of Increasing Duration of Diabetes Mellitus Type -2 on Glycated Hemoglobin and Insulin Sensitivity. Indian J Clin Biochem 21: 42-146.

36. Tonstad S, Butler T, Yan R, Fraser GE (2009) Type of vegetarian diet, body weight, and prevalence of type 2 diabetes. Diabetes Care 32: 791-796.

37. Kabiruddin H, Al Mufradat M (2010) Published By Aejaz Publishing House YNM 12: 436-437.

38. Rhazi Z, Al-Hawi (2007) Central Council for Research in Unani Medicine New Delhi. Ministry of Health \& Family Welfare, Govt. of India 12: 95.

39. Baitar I, Al-Jame' Le Mufradat, Al-Advia, Wa Al-Aghzia (1999) New Delhi Central Council for Research in Unani Medicine. Ministry of Health \& Family Welfare. Govt. of India 21: 215-216.

40. Park HJ, Lee YJ, Ryu HK, Kim MH, Chung HW, et al. (2008) A randomized double-blind, placebo-controlled study to establish the effects of spirulina in elderly Koreans. Ann Nutr Metab 52: 322-328.

41. Layam A, Reddy CLK (2006) Antidiabetic Property of Spirulina. Diabetologia Croatica 2: 35-42. 